\title{
PENGELOLAAN ZAKAT PROFESI APARAT SIPIL NEGARA
}

\section{Musfira Akbar}

Pascasarjana UIN Alauddin Makassar || mmusfira_akbar23@yahoo.co.id

\begin{abstract}
Abstrak
Penelitian ini bertujuan untuk mengetahui pengelolaan zakat profesi Aparat Sipil Negara pada Badan Amil Zakat Nasional Kabupaten Maros. Penelitian ini menggunakan metode kualitatif dengan pendekatan pendekatan normatif dan pendekatan sosial keagamaan. Sumber data penelitian adalah baznas kabupaten dan wawancara dengan mustahik dan muzakki, dan pengelola/amil zakat. Hasil Penelitian ini menemukan bahwa pengelolaan zakat di Badan Amil Zakat Kabupaten Maros belum berjalan secara maksimal disebabkan masih banyak muzakki khususnya para Aparat Sipil Negara Kabupaten Maros belum melaksankan kewajibannya membayar zakat. Zakat profesi ASN di Badan Amil Zakat Nasional Kabupaten Maros belum efektif. Hal ini disebabkan karna minimnya kesadaran dan pengetahuan para Aparat Sipil Negara tentang sistem pengeluaran zakat profesi. Meskipun setiap tahunnya muzakki mengalami peningkatan tetapi belum maksimal. Pemerintah dapat berperan aktif dengan menyempurnakan peraturan daerah dan perundangundangan yang ada dan ASN sadar akan kewajiban zakat profesi. Lembaga pengelola wajib bersifat transparan, profesional, dan ankuntabel demi mewujudkan maros sejahtera.
\end{abstract}

Kata Kunci : Pengelolaan, zakat profesi 



\begin{abstract}
This study aims to determine the management of professional zakat of the State Civil Apparatus at National Zakat Agency, Maros Regency. This study uses a qualitative method with a normative approach and socio-religious approach. Data source the research was the district baznas and interviews with mustahik and muzakki, and manager / amil zakat. The results of this study found that the management of zakat in the Amil Body Maros Regency's zakat has not run optimally because there are still many muzakki especially the State Civil Servants of Maros Regency have not carried out their obligations pay zakat. ASN profession alms in the National Zakat Agency, Maros Regency effective. This is due to the lack of awareness and knowledge of the Civil Apparatus The state regarding the professional zakat expenditure system. Even though every year muzakki experienced an increase but not maximal. The government can play an active role with perfecting local regulations and existing legislation and ASN is aware of Professional zakat obligation. The management agency must be transparent, professional, and ankuntabel in order to realize a prosperous Maros.
\end{abstract}

Keywords: Management, professional zakat

\section{PENDAHULUAN}

Zakat adalah ibadah yang memiliki peranan yang sangat penting dan strategis bila ditinjau dari aspek ajaran Islam, karena merupakan salah satu instrumen pemerataan pendapatan yang berperan dalam pembangunan kesejahteraan umat.Bila zakat dikelola dengan baik, dimungkinkan membangun pertumbuhan ekonomi sekaligus pemerataan pendapatan.

Pentingnya menunaikan zakat terutama karena perintah tersebut mengandung misi sosial, karena tujuannya sangat jelas dan berpengaruh terhadap kemaslahatan umat manusia. Tujuan yang dimaksud antara lain untuk menemukan solusi yang tepat terhadap masalah kemiskinan, kesenjangan sosial dan pemerataan pendapatan sehingga dapat meningkatkan kesejahteraan umat.

Zakat profesi atau zakat penghasilan sebenarnya merupakan istilah baru dalam fikih Islam.Eksistensi zakat profesi dalam kaitannya dengan mukallaf sebagai pelaksana hukum hampir tidak terdapat banyak masalah di kalangan umat Islam.Silang pendapat berkenaan dengan dasar hukum dan aturan yang terkait dengan pelaksanaannya hampir tidak muncul ke permukaan. Persoalan zakat, yaitu ketika ia dipandang sebagai fenomena sosial di kalangan masyarakat muslim. 
Pada zaman sekarang ini orang mendapat uang dari pekerjaan dan profesinya.Jadi, yang menghasilkan uang ada dua macam, pertama adalah pekerjaan yang dikerjakan sendiri tanpa menggantungkan diri kepada orang lain, seperti seorang dokter yang mengadakan praktik, pengacara, seniman, penjahit dan lain-lain. Kedua, pekerjaan yang dikerjakan untuk orang (pihak) lain dengan imbalan mendapatkan upah atau honorarium seperti pegawai (negeri atau swasta). Kedua macam pekerjaan tersebut jelas menghasilkan uang sebagai harta kekayaan.Dengan demikian, apakah wajib dikeluarkan zakat penghasilan itu? (Ali Hasan, 2015).

Pengembangan jenis-jenis harta yang wajib dizakatkan telah dilakukan dan telah mulai terlihat kesadaran pada sebagian masyarakat yang memiliki jenis usaha selain yang disebut dalam fiqih-fiqih klasik untuk membayar zakatnya. Kemajuan

dan pengembangan ini di bidang pendayagunaan zakat, terutama cara pendistribusiannya kepada para mustahiq. Teknik dan manejemennya harus telah mulai dikaji dan diperhatikan yang lebih sesuai untuk saat ini.Perubahan ini sangat penting mengingat adanya tiga hal penting yang harus diperhatikan dan pengelolaan zakat (pengumpulan, pendistribusian, dan pendayagunaan), ketiganya harus berjalan, agar eksistensi dan pengelolaan zakat semakin hari semakin baik dan zakat dapat berfungsi sebagaimana semestinya.

Lahirnya Undang-Undang No. 38 tahun 1999 tentang Pengelolaan Zakat yang dijabarkan dengan Keputusan Menteri Agama RI. No. 581 Tahun 1999 merupakan upaya yang positif bagi bangsa Indonesia, khususnya umat Islam untuk lebih mengoptimalkan peran dan fungsi zakat. Namun demikian ketentuanketentuan tersebut belum sempurna, karena belum memberikan kewenangan bagi pemerintah untuk mengumpulkan zakat dari pihak muzakki secara tegas dan memaksa, sebagaimana peraturan pajak.

\section{Badan Amil Zakat Nasional} (BAZNAS) merupakan badan resmi dan satu-satunya yang dibentuk oleh pemerintah berdasarkan Keputusan Presiden RI No.8 Tahun 2011 tentang tugas dan fungsi menghimpun dan menyalurkan zakat, infaq, dan sedekah 
(ZIS) pada tingkat Nasional. Zakat semakin mengukuhkan peran BAZNAS sebagai lembaga yang berwenang melakukan pengelolaan zakat secara Nasional. (Yusuf Wibisono, 2016). Dalam rangka efektivitas Peraturan Daerah No.7 Tahun 2005 tentang Pengelolaan Zakat di Wilayah Kabupaten Maros, maka Bupati Maros menghimbau ASN yang ada di wilayah itu untuk mengeluarkan zakat penghasilan. Untuk efektivitas pelaksanaan Peraturan Daerah, dihimbau keikhlasan ASN mengeluarkan zakat dan infaq setiap bulan sesuai dengan kemampuan. Untuk ASN golongan 1 diminta mengeluarkan zakat dan infaq sebesar Rp 5 Ribu sampai Rp15.000, golongan II sebesar Rp 10.000 sampai Rp 15.000, golongan III sebesar Rp 15.000sampai Rp 20.000, dan golongan VI sebesar Rp 20.000. ASN Maros yang menyalurkan zakat di Badan Amil Zakat Nasional Kabupaten Maros tahun 2010 mencapai Rp 800.000.000. (Harismanto).

Menurut Bupati Maros potensi zakat di Maros cukup tinggi namun belum dikelola dengan maksimal, sebab dari pegawai bisa dikumpulkan zakat profesi sekitar Rp 5 Miliar per tahun, dari kalangan swasta $\mathrm{Rp} 5$ Miliar pertahun, jika setahun bisa terkumpul sekitar Rp 10 Miliar. Bila potensi itu dimaksimalkan, maka bisa menggerakkan perekonomian masyarakat miskin di Maros. (Alim).

Pada tahun 2017 Badan Amil Zakat Nasional Kabupaten Maros telah berhasil mengumpulkan dana sebanyak 1,2 Miliar dari Aparat Sipil Negara Kabupaten Maros, jumlah ini sebenarnya masih kurang karena target dari Badan Amil Zakat Nasional Kabupaten Maros yaitu bisa mengumpulkan sekitar 1,6 Miliar Rupiah dari zakat profesi Aparat Sipil Negara.

\section{Landasan Teori}

\section{Pengertian Zakat Profesi}

Zakat profesi menurut putusan Tarjih Muhammadiyah adalah zakat yang dikeluarkan dari hasil usaha yang halal yang dapat mendatangkan hasil atau uang, relatif banyak dengan cara yang halal dan mudah, baik melalui keahlian tertentu maupun tidak. Sedangkan dalam pemahaman Zamzami Ahmad, zakat profesi adalah zakat penghasilan yangdidapat dan diterima dengan jalan yang halal dalam 
bentuk upah, honor ataupun gaji. maupun kedua-duanya. Penghasilan (Amiruddin Inoed, 2005).

Zakat profesi atau disebut juga sebagai yaitu زكاة كثب العمل zakat yang dikeluarkan dari sumber usaha profesi atau pendapatan/ pekerjaan/ penghasilan/ jasa. Profesi atau profession, yang berarti suatu pekerjaan tetap dengan keahlian tertentu, yang menghasilkan gaji, honor, upah atau imbalan. (Mahyuddin, 1998).

Zakat profesi adalah zakat yang dikeluarkan dari hasil usaha yang halal yang mendatangkan hasil (uang) yang relatif banyak dengan cara yang mudah, melalui suatu keahlian tertentu.

Menurut Yusuf al-Qardhawi pekerja yang menghasilkan uang ada dua macam. Pertama, pekerjaan yang dikerjakan sendiri tanpa tergantung kepada orang lain, berkat kecepatan tangan dan otak. Penghasilan yang diperoleh dengan cara ini merupakan penghasilan profesional, seperti penghasilan seorang dokter, insinyur, advokat, seniman, penjahit, dan tukang kayu. Kedua, yaitu pekerjaan yang dikerjakan seorang pihak-pihak pemerintah, perusahaan, maupun perorangan dengan memperoleh upah yang diberikan dengan tangan, otak, dari pekerjaan seperti berupa gaji, upah ataupun honorarium (Hafinuddin, 1998, 103). Dapat diartikan zakat profesi adalah zakat yang diambil dari penghasilan, dan dibarengi dengan niat yang ikhlas guna dapat membersihkan jiwa si pemberi zakat.

\section{Landasan Hukum Zakat Profesi}

Dasar hukum zakat profesi dalam al-Qur'an diantaranya terdapat dalam surah:

1) QS al-Baqarah/2: 267.

2) QS al-An'am/6: 141.

Masalah zakat dalam hadist secara umum dapat dipahami dari hadist yang diriwayatkan oleh Imam bukhari dan Muslim seperti yang ditulis dalam bukunya "Riyadh al-Shalihin": (Didin Hafiduddin, 1998).

عَنْ أبْنِ عَبَّاس رضِي الله عنها أنَّ النَبِيَ صلِى

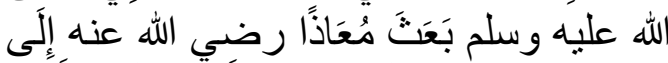

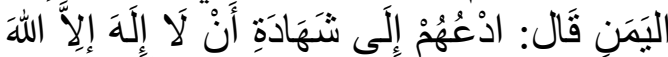

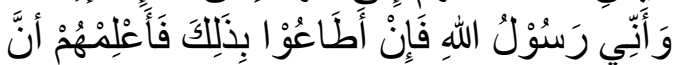

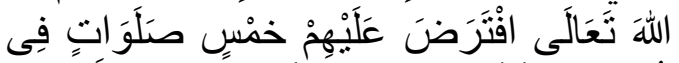

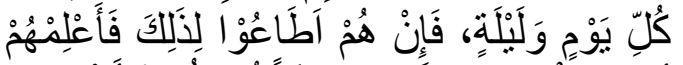

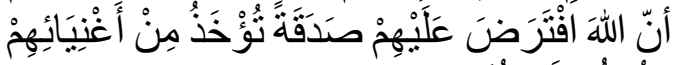

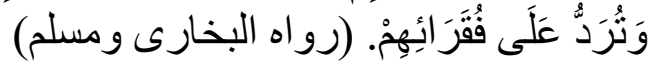
Terjemahnya:

Dari Ibnu Abbas ra, bahwasanya Nabi saw telah mengutus Mu'az ra ke Negeri Yaman, dan beliau berpesan: Ajaklah mereka kepada syahadatainjika mereka 
memattuhinya,maka beritahukan bahwa Allah telah mewajibkan kepada mereka shalat lima waktu sehari semalam, dan bila mereka mematuhinya, bahwa beritahukan bahwa Allah telah mewajibkan kepada mereka zakat pada harta kekayaan mereka, d pungut dari orang-orang kaya dari mereka dan dibagikan kepada orang-orang fakir miskin dari mereka (H.R. Bukhari).

Dari uraian di atas memberikan pemahaman bahwa setiap orang yang memiliki harta dari hasil usahanya (penghasilan), menekankan adanya kepedulian terhadap sosial masyarakat.Ada masyarakat yang tingkat ekonominya rendah maka dari itu mereka memiliki hak atas harta yang dimiliki.

\section{Tujuan Pemanfaatan Zakat Profesi}

Zakat merupakan harta yang diberikan oleh yang memiliki kelebihan harta kepada orang-orang yang hidup dalam kekurangan sebaiknya diberikan sesuai dengan tujuan dan sasaran zakat tersebut. Menurut Departemen Agama Republik Indonesia zakat hendaknya digunakan untuk hal-hal sebagai berikut: (Eko Supsayitno, 2005).
a. Memperbaiki Taraf Hidup
b. Pendidikan dan Beasiswa
c. Mengatasi Ketanagakerjaan dan Pengangguran

d. Program Pelayanan Kesehatan

e. Panti Asuhan

f. Sarana Peribadatan

4. Yang berhak Menerima Zakat

\section{Profesi}

Delapan ashnaf yang dinyatakan Allah sebagai yang berhak menerima zakat itu secara berurutan adalah sebagai berikut: (Salim Bahreisy dan Said Bahreisy, 2005).

a. Orang fakir.

b. Orang miskin.

c. Amil.

d. Muallaf.

e. Riqab.

f. Gharimin.

g. Sabilillah.

h. Ibnu sabil.

\section{Nisab, Haul dan Kadar Zakat}

\section{Profesi}

Sebagaimana dalam Islam yang tidak mewajibkan zakat kepada seluruh harta benda, baik itu sedikit maupun banyak. Tetapi mewajibkan atas harta yang mencapai nisab, terlepas dari hutang dan mencukupi seluruh kebutuhan pokoknya. Hal ini untuk menetapkan golongan orang kaya yang wjaib zakat, karena zakat hanya diambil dari orang yang kaya (yang mencapai kemampuan). (Muhammad, 2002).

Mengenai besarnya nisab zakat profesi, terdapat perbedaan dari para 
ulama. Dikarenakan tidak adanya dalil tegas mengenai zakat profesi, para ulama menggunakan qiyas dengan melihat illat yang sama dengan aturan zakat yang sudah ada. Akan tetapi, terjadi banyak masalah karena zakat profesi ini harus diqiyaskan kemana. Untuk lebih jelasnya, akan dianalisis satu persatu tentang qiyas zakat profesi ini. Dalam fatwa Majelis Ulama Indonesia (MUI) Nomor 3 Tahun 2003 disebutkan bahwa: (Khozainul Ulum, 2014).

a. Zakat penghasilan dapat dikeluarkan pada saat menerima jika sudah cukup nisab.

b. Jika tidak mencapai nisab, maka semua penghasilan dikumpulkan selama satu tahun; kemudian zakat dikeluarkan jika penghasilan bersihnya sudah cukup nisab.

Para ulama baik salaf (terdahulu) maupun khalaf(belakangan) memiliki perbedaan pendapat tentang jenis zakat harta hasil profesi ini, sebagai berikut:

a. Sebagai ahli fikih berpendapat untuk meng-qiyas-kannya dengan zakat harta mustafad (harta yang masuk dalam kepemilikan seseorang setelah sebelumnya tidak dimilki) yang mana harta yang didapat dari pekerjaan digabungkan dengan harta tunai lainnya dan semuanya dizakati diakhir haul jika mencapai nisab sebesar $2,5 \%$.

b. Sebagian lagi meng-qiyas-kannya zakat naqdain (emas dan perak) dan zakat dihitung atas dasar 2,5\% dari pendapatan bersih setelah dikurangi pembiayaan untuk memperoleh pendapatan dan nafkah kebutuhan pokok hidup, jika mencapai nisab pada dua sisi haul (awal dan akhir haul). Semua harta tunai yang belum dizakati bisa digunakan dengan pendapatan bersih tersebut.

Pendapat yang diambil oleh mayoritas ahli fikih kontemporer dan telah ditetapkan oleh lembaga zakat internasional. Pendapat ini berdasarkan atas beberapa hal: (Zainuddin, 2013).

a. Wajib memotong pembiayaan untuk meraih pendapatan, nafkah pokok kehidupan dan utang, yang mana sebagian syarat tunduknya harta terhadap zakat adalah ia merupakan kelebihan dari kebutuhan atau bebas dari utang.

b. Sulit meng-qiyas-kan haul pada setiap kelompok keuangan dan 
memperhitungkan nisab dalam dua sisi haul (awal dan akhir).

c. Semakin besar usaha dan tenaga yang dikeluarkan untuk meraih pendapatan maka tarif zakat semakin kecil dan ini terpenuhi dalam zakat profesi yang mana harga zakatnya $2,5 \%$.

Syaikh Muhammad al-Ghazali menganalogikan zakat profesi kepada zakat pertanian. Sehingga, berlaku nisab pertanian (menurut Intruksi Menteri Agama Nomor 5 Tahun 1991: 750 kg beras), tetapi tidak berlaku haul. (Zainuddin, 2013). Zakat profesi, seperti zakat pertanian, dikeluarkan kapan saja kita memperoleh penghasilan (keluarkan zakatnya pada saat menunainya). Bila pertanian menggunakan irigasi, maka zakatnya $5 \%$, dan bila bila pertanian itu mengambil air dari langit, maka dikeluarkan $10 \%$. Jadi, kalau diperkirakan zakat profesi itu seperti sawah yang diairi irigasi atau air hujan, maka konglomerat tampaknya kebanyakan mengambil air dari langit.

Nisab zakat pertanian adalah $750 \mathrm{~kg}$ beras. Untuk mengetahui jumlah gaji pegawai yang besarnya setara dengan zakat pertanian, maka harus dikonversikan dengan harga minimal beras dalam waktu dan wilayah setempat, menjadi:

750 kg x Rp $2.000=\operatorname{Rp} 1.500 .000$

\section{Menghitung Zakat Profesi}

Menurut Yusuf Qardhawi perhitungan zakat profesi dibedakan 2 (dua) cara: (Zainuddin, 2013)

a. Secara langsung, zakat dihitung dari $2,5 \%$ dari penghasilan kotor secara langsung, baik dibayarkan bulanan atau tahunan. Metode ini lebih tepat dan adil bagi mereka yang diluaskan rezekinya oleh Allah.

b. Setelah dipotong dengan kebutuhan pokok, zakat dihitung 2,5\% dari gaji setelah dipotong dengan kebutuhan pokok. Metode ini lebih adil; diterapkan oleh mereka yang penghasilannya pas-pasan.

\section{METODE PENELITIAN}

Penelitian ini termasuk dalam kategori field research yang bersifat kualitatif yang berupaya untuk mendeskripsikan dengan menginterpasikan data yang terkumpul dari proses penelitian di wilayah Maros.

Pendekatan penelitian ini adalah pendekatan normatif dan sosial agama berkenaan dengan rumusan tentang 
tentang pengelolaan zakat profesi ASN Kabupaten Maros, disamping untuk melacak tradisi penunaian zakat profesi yang dilakukan ASN.

Sumber data digunakan penelitian terdiri atas dua yakni data sekunder dan data primer. Data sekunder diperoleh dari buku, jurnal dan hasil penelitian kepustakaan, dan dokumen berupa hasil penelitian. Sedangkan data primer diperoleh dari muzakki yaitu ASN, amil zakat.

Metode yang dilakukan dalam pengumpulan data dalam penelitian ini adalah wawancara dan dokumentasi.

\section{HASIL DAN PEMBAHASAN}

a. Pengelolaan Zakat di Badan Amil Zakat Nasional Kabupaten Maros

Adapun pengelolaan zakat di Badan Amil Zakat Nasional (BAZNAS) di Kabupaten Maros yaitu:

\section{Pengumpulan}

Pengumpulan dana zakat adalah kegiatan pengumpulan dana zakat dari para muzakki kepada lembaga zakat untuk disalurkan kepada yang berhak menerima sesuai dengan ukurannya. Pengempulan dana zakat, infaq, dan sedekah yang dilakukan oleh Badan Amil Zakat Nasional (BAZNAS) Kabupaten Maros dengan cara menerima atau mengambil langsung dari muzakki. Badan Amil Zakat Nasional (BAZNAS) Kabupaten Maros bekerjasama dengan Bank dalam pengumpulan zakat, infaq dan sedekah (ZIS). Badan Amil Zakat Nasional (BAZNAS) menyiapkan strategi dalam mengumpulkan dana zakat, infaq dan sedekah (ZIS) di Kabupaten Maros yaitu strategi publikasi dan strategi administrasi.

2. Pendistribusian dan Pendayagunaan Pendistribusian adalah kegiatan membagikan sejumlah harta yang telah dikumpulkan oleh lembaga zakat dari muzakki untuk dibagikan kepada yang berhak menerimanya baik secara konsumtif ataupun secara produktif. Adapun pendayagunaan adalah bagaimana cara atau usaha dalam mendatangkan hasil dan manfaat yang lebih besar dari dana zakat yang diberikan.

Pada pendistribusian ini Badan Amil Zakat Nasional (BAZNAS) Kabupaten Maros menyalurkan zakat kepada mustahiq yang berhak menerimanya baik secara konsumtif yaitu penyaluran dana yang langsung dibutuhkan oleh mustahiqdan pendistribusian secara produktif yaitu 
pemberian dana berupa bantuan produktif untuk meningkatkan taraf hidup mereka.

\section{Bantuan konsumtif adalah} bantuan langsung yang diberikan kepada para masyarakat yang berhak menerima bantuan. Program bantuan konsumtif ini pihak Badan Amil Zakat Nasional (BAZNAS) Kabupaten Maros memberikan kepada 10 kepala rumah tangga dalam satu kelurahan se Kabupaten Maros.

Badan Amil Zakat Nasional (BAZNAS) Kabupaten Maros untuk memenuhi tuntutan Undang-Undang Nomor 23 Tahun 2011 memiliki beberapa program pendayagunaan untuk memberdayakan perekonomian seorang mustahiq. Program pemberdayaan tersebut diantaranya ialah program produktif.Program pemberdayaan ini diharapkan untuk membantu seorang mustahiq dapat memiliki usaha mandiri untuk memenuhi kebutuhannya.

Bantuan produktif adalah
bantuan yang diberikan berupa
pelatihan-pelatihan kepada mustahiq,
dengan adanya bantuan ini mustahiq
dapat mengembangkan kemampuannya
agar mampu keluar dari kesenjangan

sosial. Badan Amil Zakat Nasional (BAZNAS) Kabupaten Maros dengan bantuan produktif memiliki program suntikan DP tanpa bunga.

b. Zakat Profesi ASN di Badan Amil Zakat Nasional Kabupaten Maros Zakat profesi adalah zakat yang dikeluarkan dari hasil usaha yang halal yang mendatangkan hasil (uang) yang relatif banyak dengan cara yang mudah, melalui suatu keahlian tertentu. Kabupaten Maros memiliki potensi yang cukup besar mengenai pengelolaan zakat. Saat ini Badan Amil Zakat Nasional (BAZNAS) Kabupaten Maros masih mengoptimalkan zakat profesi dari Aparat Sipil Negara (ASN) di Kabupaten Maros.

Badan Amil Zakat Nasional (BAZNAS) Kabupaten Maros diharapkan mampu mengelola zakat profesi dengan baik, melihat jumlah Aparat Sipil Negara (ASN) di Kabupaten Maros sebanyak 6661 orang yang beragama Islam.

\section{Pihak BAZNAS Kabupaten}

Maros sudah melaksanakan kegiatan sosialisasi mengenai Undang-Undang No 11 Tahun 2011 tentang Pengelolaan Zakat kepada Aparat Sipil Negara di tiap kantor. Dengan adanya sosialisasi 
BAZNAS mengharapkan kesadaran pegawai untuk mengeluarkan zakatnya dan membantu masyarakat yang membutuhkan atau kurang mampu.

Untuk memudahkan pelayanan zakat maka dibentuklah Unit Pengumpulan Zakat (UPZ), yaitu suatu organisasi yang di bentuk oleh Badan Amil Zakat Nasional (BAZNAS) dengan tugas melayani muzakki yang menyerahkan zakatnya. Pembentukan Unit Pengumpulan Zakat (UPZ) ini dilakukan disetiap Desa, Kelurahan, dan Instansi dengan tujuan untuk melakukan pengumpulan zakat, infaq, dan sedekah di unit masing-masing dengan menggunakan formulir yang telah dibuat oleh Badan Amil Zakat Nasional (BAZNAS) dan hasilnya diberikan kepada bagian pengumpulan zakat.

Sebagian Aparat Sipil Negara sudah memahami dalam hal berzakat, melihat dari golongan dia berhak atau diwajibkan mengeluarkan zakat dari hasil pendapatannya. Sebagaimana yang di ungkapkan Muhammad dalam bukunya mengatakan pendapatan dari hasil kerja pada sebuah instansi, baik pemerintah maupun swasta. Pendapatan dari jenis ini biasanya bersifat aktif atau relatife ada pemasukan/pendapatan yang diterima secara periode atau perbulannya.

Penulis menyimpulkan bahwa masih kurangnya kesadaran Aparat Sipil Negara dalam hal berzakat, meskipun sudah ada beberapa Aparat Sipil Negara mulai menyadari akan pentingnya berzakat.

c. Faktor Pendukung dan Penghambat dalam Pengelolaan Zakat Profesi di Badan Amil Zakat Nasional (BAZNAS) di Kabupaten Maros Menggali potensi zakat di Kabupaten Maros secara umum dipengaruhi beberapa faktor pendukung dan penghambat. Kesuksesan suatu lembaga yaitu tergantung pengelolaannya. Zakat merupakan pondasi ekonomi umat Islam yang memiliki peluang besar. Dalam hal ini berupaya memaparkan factor pendukung dan penghambat serta solusinya, sebagai berikut:

1) Faktor Pendukung

a) Potensi Zakat Profesi

b) Dukungan Pemerintah

c) Zakat Sebagai Kewajiban Umat Islam

2) Faktor Penghambat

a) Pengelola Zakat

b) Peran Pemerintah Yang Belum Optimal

c) Rendahnya Kesadaran ASN 


\section{PENUTUP}

Pengelolaan zakat di Badan Amil Zakat Kabupaten Maros belum berjalan secara maksimal karna masih banyak muzakki khususnya para Aparat Sipil Negara Kabupaten Maros belum melaksankan kewajibannya membayar zakat. Tetapi ada beberapa program yang sudah terealisasi di BAZNAS Kabupaten Maros. Seperti keberhasilan program pemberdayaan zakatnya, program produktif Maros sejahtera, dan BAZNAS Kabupaten Maros telah memberdayakan perekonomian beberapa mustahiq menjadi lebih produktif, bahkan ada beberapa mustahiq saat ini telah berubah peran menjadi salah seorang muzakki.

Zakat profesi ASN di Badan Amil Zakat Nasional Kabupaten Maros belum efektif. Hal ini disebabkan karna minimnya kesadaran dan pengetahuan para Aparat Sipil Negara tentang sistem pengeluaran zakat profesi. Meskipun setiap tahunnya muzakki mengalami peningkatan tetapi belum maksimal.

Faktor pendukung dalam pengelolaan zakat profesi ASN di Kabupaten Maros adalah potensi zakat profesi, dukungan pemerintah, dan zakat sebagai kewajiban umat Islam dan faktor penghambat dalam pengelolaan zakat profesi ASN di Kabupaten Maros adalah rendahnya tingkat kuantitas maupun kualitas para pengelola zakat, peran pemerintah yang belum optimal, serta rendahnya kesadaran para Aparat Sipil Negara di Kabupaten Maros.

\section{DAFTAR PUSTAKA}

Al-Juzairī, Abdurrahman, Kitāb al-Fiqh alā al-Mazhābib al-Arbā'ah, Beirut: Dār al-Fikr, 1998.

Al-urthubi. Al-Jami' Li Ahkam al-Quran, Cet. II; Jilid 7-8, 1993.

Bahreisy, Salim dan Bahreisy Said. Terjemah Singkat Tafsir Ibnu Katsir Jilid 4, Surabaya: Bina Ilmu, 2005.

Basri, Ikhwan Abidin. Islam dan Pembangunan Ekonomi, Jakarta: Gema Insani Press, 2005.

Bungin, Burhan. Analisis Data Kualitatif: Pemahaman Filosofis dan Metodologis ke Arah Penguasaan Model Aplikasi, Cet. III; Jakarta: Rajawali Press, 2009.

Departemen Agama RI. Al-Qur'an Terjemahanya, Bandung: Cordoba Internasional Indonesia, 2012. 


\section{J-HES}

Jurnal Hukum Ekonomi Syariah

Volume 2, No. 2, Juli-Desember 2018 | p-ISSN: 2549-4872 | e-ISSN: 2654-4970

Departemen Pendidikan dan Kebudayaan. Kamus Basar Bahasa Indonesia, Jakarta: Balai Pustaka, 1997.

Fowler, W.H dan Fowler, G.F, The Concies Oxford Dictionory of Curent English, London: Oxford, 1952

Hafidhuddin, Didin. Zakat Dalam Perekonomian Modern, Cet. II; Jakarta: Gema Insani, 2002.

Hamid, M. Arifin. Hukum Zakat Pengembangan dan Pendayagunaannya (Urgensi dan Aplikasinya di Indonesia), Makassar: PT. Umitoha Ukhuwah Grafika, 2006.

Hasan, Ali. Zakat dan Infak Salah Satu Solusi Mengatasi Problem Sosial di Indonesia, Jakarta: Kencana Prenada Media Group, tth.

Huda, Nurul. Lembaga Keuangan Islam Tinjauan Teoritis dan Praktis, Cet II; Jakarta: Prenada Media Group, 2013.

Inoed,Amiruddin. Anatomi Fiqh Zakat, Yogyakarta: Pustaka Pelajar, 2005.

Ismail, Ibrahim. Rekonseptualisasi Zakat Profesi dalam Membangun Ekonomi Umat di tengah Masyarakat Prular, Tesis 2011.

Karim, A Adiwarman. Ekonomi Islam Suatu Kajian Kontemporer, Jakarta: Gema Insani Pers, 2001.

Lubis, Suhrawadi K. Hukum ekonomi Islam, Jakarta: Sinar Grafika, 2000.

Mahyudin. Masailul Fiqhiyah, Jakarta: Kalam Mulia, 1998.

Marimin, Agus. "Zakat Profesi (Zakat Penghasilan Menurut Hukum Islam)". Jurnal Ilmiah Ekonomi Islam, vol. 01, No. 01 (2005).

Mas'udi, asdar. Menggagas Ulang Zakat, Bandung: Mizan, 2005.

------Metode Penelitian Kualitatif, Kuantitatif dan R\&D, Cet. XI; Bandung: Alfabeta, 2010.

Mubarok, Jaih. Modifikasi Hukum Islam, Jakarta: PT. Raja Grafindo Persada, 2002.

Muchlis, Saiful.Akuntansi Zakat, Cet I; Makassar: Alauddin University Press, 2014.

Mufriani, Arief. Akuntansi dan Manajemen Zakat, Jakarta: Kencana, 2006.

Muhammad. Zakat Profesi; Wacana Pemikiran dalam Fiqih Kontomporer, CetII; Jakarta: Salemba Diniyah, 2002.

Nasution, Edwin Mustafa. Pengenalan Ekslusif Ekonomi Islam, Cet 2; Jakarta: Kencana Prenada Media Group, 2007.

Nawawi, Hadari. Metode Penelitian Sosial, Yogyakarta: UGM-Press, 1987.

-------Panduan Organisasi Pengelola Zakat, Jakarta: Direktorat Pemberdayaan Zakat, 2008.

------Panduan Tentang Zakat, Infaq, dan Sedekah, Jakarta: Gema Insani Press, 1998.

Patombongi, Said M. Wakil Ketua Badan Amil Zakat Nasional Kabupaten Maros, 2017. 


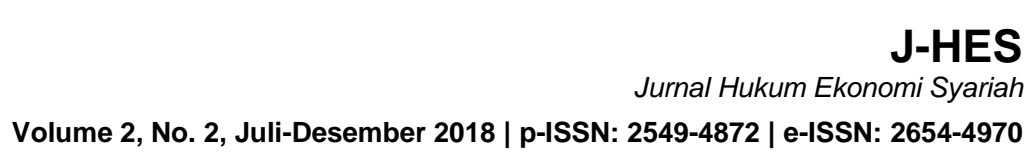

-------Pedoman Zakat 9 Seri, Jakarta: Direktorat Pemberdayaan Zakat, 2009.

-------Peraturan Perundang-undangan Pengelolaan Zakat, Jakarta: Direktorat Pemberdayaan Zakat, 2008.

Qadir, Abdurrahman. Zakat (dalam dimensi mahdah dan sosial), Jakarta: Raja Grafindo, 2001.

Qadrawi, Yusuf. Hukum Zakat; Studi Kompratif Mengenai Status dan Filsafat ZakatBerdasarkanQur'an dan Hadis, Tej. Cet.IV; Jakarta: Litera Antar Nusa dan Mizan, 2004.

Rosyadi, Rahmat. Formalisasi Syariat Islam dalam Perspektif Tata Hukum Indonesia Bogor: Penerbit Ghalia Indonesia, 2006.

Rozalinda. Ekonomi Islam Teori dan Aplikasinya pada Aktivitas Ekonomi, Cet III; Jakarta: PT Rajagrafindo Persada, 2016.

Rusyd, Ibnu. Bidayah al-Mujtahid terj, Jilid 2 Cet I; Semarang: asy-Syifa, 1990.

Sabiq, Sayyid. Fiqhus Sunnah diterjemahkan oleh Mahyuddin Syaf dengan judul Fiqih Sunnah Jilid 3, Cet I; Bandung: Al-Ma'arif, 1990.

Satori, Djam'an dan Komariah, Aan.Metodologi Penelitian Kualitatif, Cet. V; Bandung: Alfabeta, 2013.

Shihab,Quraish. Tafsir Al Misbah: Pesan, Kesan dan Keserasian Al-Qur'an, Cet V vol 15; Jakarta: Lentera Hati, 2005.

Sugiyono.Memahami Penelitian Kualitatif, Cet. VII; Bandung: Alfabeta, 2012.

Suprayitno, Eko. Ekonomi Islam: Pendekatan Ekonomi Makro Islam dan Konvensional, Yogyakarta: Graha Ilmu, 2005.

Syahatah, Husein. Cara Praktis Menghitung Zakat, Penterjemah Mujahidin Muhayan, Kalam Pustaka, 2005.

Syarifuddin, Amir. Garis-Garis Besar Fiqih, Jakarta: Prenada Media, 2003.

Syarifuddin. Implementasi Zakat Profesi di Kalangan PNS dan TNI/POLRI di Kecematan . 